\title{
PHYSIOLOGICAL ASPECTS OF BEHAVIOUR OF SOWS AND PIGLETS DURING THE LACTATION PERIOD
}

\author{
M. Joksimović-Todorović ${ }^{1}$, V. Davidović́ ${ }^{1}$, B. Živković ${ }^{2}$ \\ ${ }^{1}$ Faculty of Agriculture, 11080, Belgrade-Zemun, Republic of Serbia \\ ${ }^{2}$ Institute for Animal Husbandry, 11080, Belgrade-Zemun, Republic of Serbia \\ Corresponding author: miratodo@agrif.bg.ac.rs \\ Review paper
}

\begin{abstract}
Maternal ability represents complex interactions between different forms of behaviour and physiological characteristics. Behaviour and metabolic processes are partly under the control of endocrine and nervous systems. Sows are different from other mammals, in that sows bear a large number mature baby, capable immediately to suckling. Post partum anabolic processes become catabolic, giving priority to dairy gland in relation to other tissues. Maximum secretated milk takes place betwen 2. and 3. week. Sows lost in body mass and it is appeared the change in value of some bloods parameters. Haemotologic analyses have suggested the increase in total number of leukocytes and neutrophilic granulocytes and the decrease in the number of lymphocytes, monocytes and eosinophils on the first day postpartum. In the third and fourth week of lactation a statistically significant fall in the number of leukocytes and granulocytes in relation to the first day was observed, along with a significant increase in limphocytes, monocytes and eosinophils. Erythrocyte count, haemoglobin concentration and haematocrit value decreased during the lactation period. Level of glucose in plasma is low (it is decreasing for more than 50\%), while the level of urea is high, due to huge proteins available. It can also be noticed that there is a high mobilisation of body fat an increasing level of NEFA (non-esterified fatty acid). Secretion of milk is under control prolactin and oxytocin. Oxytocin affects on maternal behaviour and prolactin is linked with timing of suck.
\end{abstract}

Key words: behaviour, sow, piglet, lactation.

\section{Introduction}

Hormonal changes, prior and post parturition do impel the sow to build a nest. It is one of the main characteristics of sow behaviour started by an individual $24 \mathrm{~h}$ or $15 \mathrm{~h}$ prior parturition at the latest (Damm et al., 2003), and is the result of increased secretion of prostoglandin $\mathrm{F}_{2 \text { alfa }}$ (Burne at al., 2001). Enclosed housing 
systems hinder this need what is frustrating to sows, especially in the phase when pregnant sows are being removed into buildings in which they are kept individually in impacted boxes (Vučinić and Hristov, 2002; Hötzel et al., 2005). In order to avoid these stress situations, a week prior parturition it is necessary to supply sow with suitable material for nest building-up (Stanković et al., 2007). The use of jammed boxes in farrowing houses represents the problem discussed for many years to the purpose to protect the welfare of both sows and piglets (Hristov et al., 2001).

The increased level of cortisol can indicate frustrations when the sows deprive themselves of natural behaviour (Mason at al., 2001; Thodberg et al., 2002). Numerous physiological and biochemical studies have been used for the estimation of welfare and they are mostly concerned with the determination of adrenal gland and hypophysis hormones concentration, especially glucocorticosteroids (GC) in blood (Hristov and Bešlin, 1991; Hristov et al., 2008). Increased levels of cortisol, insulin and thyroid hormones indicate the presence of stress (Joksimović Todorović et al., 2007). Changes occurring in the hypothalamushypophysis-adrenal cortex system or vegetative nervous system are not reflected in the form of some psychological reaction but they are reflected on the homeostatic metabolic processes and animal immunity system (Joksimović Todorović et al., 2008).

It is necessary to bring the sow into a certain condition by the farrowing term. Diets must be of good quality, protected against contamination and development of mycotoxins (Jokić et al., 2003; Joksimović Todorović et al., 2004; Petrović et al., 2007). After parturition the organism of individual passes from anabolic to catabolic state when sows lose their body mass and the concentrations of some hormones, concentration of glucose, urea and non-esterificated fatty acids (NEFA) in blood changes (Algers and Uvnäs-Moberg, 2007). The most intensive catabolic processes in sows occur in the 3rd and 4th lactation week when piglets reach the plateau in their daily liveweight gain.

\section{Metabolic changes in sows from prepartal period to weaning}

Maternal ability represents complex interactions between different forms of behaviour and physiological characteristics. Factors that influence sow maternal behaviour are: litter size, vitality, health and regime of nutrition. Sows differ from other domestic mammals because they bring forth a large number of mature youngs capable for immediate suckling. Suckling is initiated by sow by calling the piglets making some grunting sounds while piglets try to stimulate sow's teats for milk ejection by tactile teasing (Vučinić and Radenković-Damjanović, 2000). During gestation mother`s body reserves are increasing in order to provide milk production after parturition. After parturition the organism passes from anabolic into catabolic 
state so that mammary gland gains priority in relation to other tissues (̌́pinka et al., 2002). Level of catabolic processes during lactation depends on nutritive value and quantity of milk secreted and it is most intensive between 2nd and 3rd lactation week. Sows lose their body mass and there also occurs the change in the concentration of some blood plasma ingredients (lower activity of lipoproteinlipases and the rate of fatty acids synthesis) even when sows are fed ad libitum. Diet intake cannot compensate completely the needs for milk production and energy balance is usually negative. High demands for energy lead to abundant catabolic processes especially in the third week (Kraetzl et al., 1998).

During lactation the level of glucose in plasma is low since about $50 \%$ glucose is used by mammary gland for milk production. Level of glucose in blood may be increased in the first week of lactation but after that it significantly decreases in the third and fourth week. It is possible that glucose is not directly used from body reserves for milk production since pigs obtain high levels of starch by nutrition. High levels of urea indicate the use of high levels of muscular proteins although this assertion is inconsistent and is not in direct relationship with loss of body mass. Unsaturated fatty acids as a product of fats metabolism are reliable sign of catabolic state and only small quantities come from food. Level of NEFA increases at the end of gestation and it is the highest in the middle and at the end of lactation. Their concentration is used mostly as a measure of energy status post parturition and catabolism of fats in sows (Hulten et al., 1993).

During the lactation period, there occurs in sows a significant change in the values of haematologic parameters. On the day of parturition (1-6h after parturition) was found leukocytosis, neutrophilia and lymphopenia in sows (Thorn, 2000; Damgaard et al., 2009; Joksimovic Todorovići et al., 2010a). In the third and fourth week of lactation a statistically significant fall in the number of leukocytes and granulocytes in relation to the first day was observed, along with a significant increase in limphocytes, monocytes and eosinophils (Joksimovic Todorovići et al., 2010a). Research conducted by Dungan et al. (1995), Thorn (2000), Žvorc et al. (2006) suggest that in sows during lactation period reduces the number of red blood cells, haemoglobin and haematocrit value, which is consistent with studies Joksimovic Todorovići et al. (2010b).

\section{Sow endocrine system}

Maternal behaviour and metabolic processes are partly under the control of endocrine system. Building-up of nest for farrowing is induced by the increase of the concentration of prolactin, while the increase of oxitocyne is perceived at the end of nest building. Maintaining of lactation depends on the level of prolactin, while the oxitocin is esential for the reflex of secreting milk. Concentration of oxitocin increases abruptly during suckling, reaches peak levels during milk 
ejection when the stimulation of teats by piglets is sufficient. After milk ejection the oxitocin returns to its basic level.

Prolactin is the most important hormone which promotes and maintains lactation. Level of prolactin increases in the last week of gestation and attains maximal concentration immediately prior parturition and in the first two weeks of lactation (Kraetzl et al., 1998). Secretion of prolactin is stimulated by teats massage, its concentration increases gradually, not abruptly as is the case with the level of oxitocin, and greatest confirmed level is $10-20$ min after suckling. During lactation the level of prolactin decreases as a consequence of reduced teats massage. This has a positive effect on the number of insuline receptors in mammary gland, and it is thought that it plays role in determination of metabolic functions, especially in arranging sources for milk production.

Insulin is a promoter of glucose and aminoacids utilization from peripheral body tissues by reduced use of nutritive matters for milk production. The insuline reduction during maximal lactation is a physiological response to abundant use of glucose for milk production. Levels of insuline are higher in sows that have lost less body mass during lactation so that catabolic processes are of less intensity (Kraetzl et al., 1998). Insulin directly effects milk production because after parturition the number of insuline receptors in fat tissue decreases while their number in mammary complex increases considerably. This leads to reduced lipogenesis in fat tissue, but increases the sensitivity of mammary tissue against insuline in spite of its reduced concentration in plasma.

\section{Mortality in piglets}

Mortality in piglets is ethicaly and economicaly unacceptable in modern pig production. Research must be focused towards reducing this problem. Mortality in piglets is directly or indirectly associated with maternal abilities: piglets starvation, crushing of piglets and other factors to which they are exposed during lactation period. Farrowing in jammed housing system has decreased the mortality of piglets but on the other hand by this system a welfare of sows is influenced in a negative way. Building of nest and natural parturition are impossible in this housing system because of which situation the sows undergo stress situation (level of cortisol and adenocorticotropine hormone is increased) (Broom and Johnson, 1993). Impacted housing system also has negative consequences on the health of pigs (incidence of MMA syndrome) and difficulties during farrowing (prolonged farrowing especially in gilts) (Hristov et al., 2008).

Mortality in piglets differs depending on housing system. Expressed in percentages it ranges from 10 and $20 \%$ (perinatal mortality, starvation and crushing). Hungry piglets stay longer on teats trying to stimulate milk secretion. These piglets are more easily crushed by mother or they die of starvation and/or 
trauma caused by mother. Starvation is a cause of piglets death in about $50 \%$ cases being the greatest on the first day after farrowing. Approximately about $75 \%$ total mortality occurs in the first week of lactation. Physical factors such as suffocating in the course of parturition, trauma, starvation and septicaemia are the most often causes in the first four days of the life of piglets. Viral and bacterial infections are the causes of piglets mortality in later period of lactation.

\section{Behaviour of piglets during nursing}

Social hierarchy is being established by piglets immediately after their birth. The first pair of teats which produce more milk than other teats are sucked by the dominant piglets. They save their places during suckling and behave agressively towards piglets who try to take over their places. Suckling includes several phases. First the sow makes grunting sounds by which it calls piglets to come and then they arrange themselves in a certain way. In the beginning the piglets squeeze teats by their mouths, hit them by head, and then hold them tightly, drawing them into their mouths and making vacuum. In this way milk reaches the cistern of mammary complex and piglets are starting to suckle very rapidly (Špinka et al., 2002). At the expiration of one hour after previous suckling piglets wake up and initiate suckling again. The sow lies down on its sides allowing in this way hungry piglets to suckle again. In order that suckling should be successfull the piglets indicate to sow by their behaviour that they all are present and ready for suckling (Vučinić, 2006).

Not every breast-feeding is successful. Unsuccessful breast-feeding is recognized by more intensive sow grunting during the entire time of breast-feeding. It is caused by non-releasing of oxitocin in which case the milk may not reach mammary cistern. Permanent and intensive sow grunting may indicate the presence of pain in mammary gland or that the release of oxitocin was omitted. In these cases the sow does not allow the access to piglets or she lies down on its abdominal side. By lying on the stomach the sow is cooling its mammary complex in case the acute inflammation has occurred there.

\section{Conclusion}

Behaviour of animals depends on: cognitive, neurophysiological, motor, motivation components and subjective feelings. In order that sows could express their natural behaviour it is necessary to provide them with quality diet in sufficient quantities, suitable space and protection against infective and non-infective diseases. If the environment is less restrictive the sows can express their natural 
behaviour but if maternal ability is impaired it cannot be compensated by subsequent improvement of environment.

\title{
Fiziološki aspekti ponašanja krmača i prasadi u toku laktacionog perioda
}

\author{
M. Joksimović Todorović, V. Davidović, B. Živković
}

\section{Rezime}

Materinska sposobnost predstavlja kompleksne interakcije između različitih oblika ponašanja i fizioloških karakteristika. Ponašanje i metabolički procesi su delimično pod kontrolom endokrinog i nervnog sistema. Krmače se razlikuju od drugih sisara po tome što rađaju veliki broj zrelih mladih sposobnih da odmah sisaju. Nakon partusa anabolički procesi prelaze u kataboličke, dajući tako prioritet mlečnoj žlezdi u odnosu na druga tkiva. Maksimalna sekrecija mleka odvija se između 2. i 3. nedelje. Krmače gube telesnu masu i dolazi do promena vrednosti pojedinih parametara u krvi. Hematološke analize su ukazale na povećanje ukupnog broja leukocita i neutrofilnih granulocita i smanjenje broja limfocita, monocita i eozinofila prvog dana po partusu. Treće i četvrte nedelje laktacije, došlo je do statistički značajnog pada broja leukocita i granulocita $u$ odnosu na prvi dan, a značajnog porasta limfocita, monocita i eozinofila. Broj eritrocita, koncentracija hemoglobina i vrednost hematokrita smanjuju se tokom laktacionog perida. Nivo glukoze u plazmi je veoma nizak (niži je za preko 50\%), dok je nivo ureje visok usled obimnog iskorišćavanja proteina. Takođe je ustanovljeno da značajna mobilizacija telesnih masti dovodi do povećanja nivoa NEFA (nezasićenih masnih kiselina). Sekrecija mleka je pod kontrolom prolaktina i oksitocina. Oksitocin utiče na materinsko ponašanje a prolaktin je u korelaciji sa dužinom sisanja.

\section{References}

ALGERS B., UVNÄS-MOBERG K. (2007): Maternal behaviour in pigs. Hormons and Behaviour, 52, 78-85.

BROOM D., JOHNSON K. (1993): Stress and Animal Welfare. Champan and Hall, London.

BURNE T.H.J., MURFITT P.J.E., GILBERT C.L. (2001): Influence of environmental temperature on $\operatorname{pgf}(2$ alpha)-induced nest building in female pigs. Appl. Anim. Behav. Sci., 71, 293-304. 
DAMGAARD B.M., MALMKVIST J., PEDERSEN L.J., JENSEN K.H., THODBERG K., JØRGENSEN E., JUUL-MADSEN H.R. (2009): The effects of floor heating on body temperature, water consumption, stress response and immune competence around parturition in loose-housed sows. Res.Vet. Sci., 86, 1, 136-145. DAMM B.I., PEDERSEN L.J., MARCHANT-FORDE J.N., GILBERT C.L. (2003): Does feed-back from a nest affect periparturient behaviour, heart rate and circulatory cortisol and oxytocin in gilts? Appl. Anim. Behav. Sci., 83, 55-76.

DUNGAN L.J., WEIST D.B., FYTE D.A., SMITH A.C., SWINDLE M.M. (1995): Normal hematology, serology, and serum protein electrophoresis values in fetal Yucatan miniature swine. Lab. Anim. Sci., 45, 285-289.

HRISTOV S., BEŠLIN R. (1991): Stres domaćih životinja. Monografija, Poljoprivredni fakultet, Beograd.

HRISTOV S., TODOROVIĆ M., RELIĆ R. (2001): Najznačajniji problemi dobrobiti svinja. Savremena poljoprivreda, 50, 3-4, 221-226, 2001.

HRISTOV S., STANKOVIĆ B., RELIĆ R., JOKSIMOVIĆ TODOROVIĆ M. (2008): Dobrobit i biosigurnost na farmama. XVIII Inovacije u stočarstvu, Beograd 27-28. novembar 2008. godine. Biotehnologija u stočarstvu Vol. 24, Poseban broj, 39-49.

HULTEN F., NEIL M., EINARSSON S., HAKANSSON J. (1993): Energy metabolism during late gestation and lactation in multiparous sows in relation to backfat thickness and interval from weaning to first oestrus. Acta vet. Scand., 34, 9-20. HÖTZEL M.J., PINHEIRO L.C., FILHO M., DALLA COSTA O.A. (2005): Behaviour of pre-parturient sows housed in intensive outdoor or indoor systems. Pesq. agropec. bras. Brasilia, 40, 2, 169-174.

JOKIĆ Ž., TODOROVIĆ M., PETROVIĆ M. (2003): Uticaj mikotoksina na neke reproduktivne pokazatelje svinja. Veterinarski glasnik, 57, Dodatak 7-8, 487-494.

JOKSIMOVIĆ TODOROVIĆ M., JOKIĆ Ž., DAVIDOVIĆ V. (2004): Značaj selena i vitamina E u ishrani svinja. XVI Inovacije u stočarstvu, Beograd 17-18. novembar 2004. godine. Biotehnologija u stočarstvu, Vol. 20 (5-6), str. 233-238.

JOKSIMOVIĆ TODOROVIĆ M., HRISTOV S., DAVIDOVIĆ V., STANKOVIĆ B. (2007): Fiziološki aspekti ponašanja i dobrobiti farmskih životinja. Prva Međunarodna konferencija o dobrobiti i biosigurnosti na farmama u Srbiji, Zemun, 14. i 15. novembar 2007. Monografija "Dobrobit životinja i biosigurnost na farmama", 65-74. Urednik D. Rudić, Poljoprivredni fakultet Zemun-Beograd. ISBN 978-86-7834-042-0.

JOKSIMOVIĆ TODOROVIĆ M., HRISTOV S., DAVIDOVIĆ V., RELIĆ R., STANKOVIĆ B. (2008): Najznačajniji oblici ponašanja goveda. Veterinarski glasnik, 62, 3-4, 131-256.

JOKSIMOVIĆ TODOROVIĆ M., DAVIDOVIĆ V., BOKAN LJ. (2010a): Leukocyte profile in sows during lactation period. Biotechnology in Animal Husbandry, 26, 3-4, 239-244. 
JOKSIMOVIĆ TODOROVIĆ M., DAVIDOVIĆ V., BOKAN LJ. (2010b): Crvena krvna slika u krmača tokom laktacionog perioda. Veterinarski glasnik, 64, 5-6, 359-365.

KRAETZL W.D., ZIMMER C., SCHNEIDER D., SCHAMS D. (1998): Secretion pattern of growth hormone, prolaktin, insulin and insulin-like growth, factor-1, in the periparturient sow depending on the metabolic state during lactation. Anim. Sci., 67, 339-347.

MASON G.J., COOPER J., CLAREBROUGH C. (2001): Frustrations of furfarmed mink. Nature, 410, 35-36.

PETROVIĆ M., STANKOVIĆ B., HRISTOV S., JOKSIMOVIĆ TODOROVIĆ M., DAVIDOVIĆ V., BOŽIĆ A. (2007): Minimalni standardi u uslovima gajenja i dobrobiti svinja. Prva Međunarodna konferencija o dobrobiti i biosigurnosti na farmama u Srbiji, Zemun, 14. i 15. novembar 2007. Monografija "Dobrobit životinja i biosigurnost na farmama", 173-185. Urednik D. Rudić, Poljoprivredni fakultet Zemun-Beograd. ISBN 978-86-7834-042-0.

STANKOVIĆ B., HRISTOV S., JOKSIMOVIĆ TODOROVIĆ M., DAVIDOVIĆ V., BOŽIĆ A. (2007): Biosigurnost na farmama svinja. Prva Međunarodna konferencija o dobrobiti i biosigurnosti na farmama u Srbiji, Zemun, 14. i 15. novembar 2007. Monografija "Dobrobit životinja i biosigurnost na farmama", 299310. Urednik D. Rudić, Poljoprivredni fakultet Zemun-Beograd. ISBN 978-867834-042-0.

THODBERG K., JENSEN K.H., HERSKIN M.S. (2002): Nest building and farrowing in sows: relation to the reaction pattern during stress, farrowing environment and experience. Appl. Anim. Behav. Sci., 77, 21-42.

THORN C.E. (2000): Chapter 168: Normal Hematology of the Pig in Feldman FB et al.: Fifth edition Schalm's Veterinary Hematology, Copyright (C) 2000 Lippincott Williams \& Wilkins, 1089-1095.

VUČINIĆ M., RADENKOVIĆ-DAMJANOVIĆ B. (2000): Dobrobit i ponašanje svinja. Biblioteka, Veterinarica, Galenika a.d., Beograd, 86.

VUČINIĆ M., HRISTOV S. (2002): Poremećaji ponašanja kao pokazatelji grešaka u gajenju životinja. Biotehnologija u stočarstvu, 18, 5-6, 161-166.

VUČINIĆ M. (2006): Ponašanje, dobrobit i zaštita životinja. Fakultet veterinarske medicine, Beograd.

ŠPINKA M., STÉHULOVÁ I., ZACHACOVÁ J., MALETINSKA J., ILLMANN G. (2002): Nursing behaviour and nursing vocalisations in domestic sows: repeatability and relationship with maternal investment. Behav., 139, 1077-1097.

ŽVORC Z., MRLJAK V., SUŠIĆ V., POMPE GOTAL J. (2006): Haematological and biochemical parameters during pregnancy and lactation in sows. Veterinarski arhiv, 76, 3, 245-253. 